Arteterapia. Papeles de arteterapia y educación para inclusión social ISSN-e 1988-8309

http://dx.doi.org/10.5209/ARTE.60558

\title{
Reseña jornada arteterapia y educación. Máster Arteterapia UPV.
}

Ana Hernández Merino

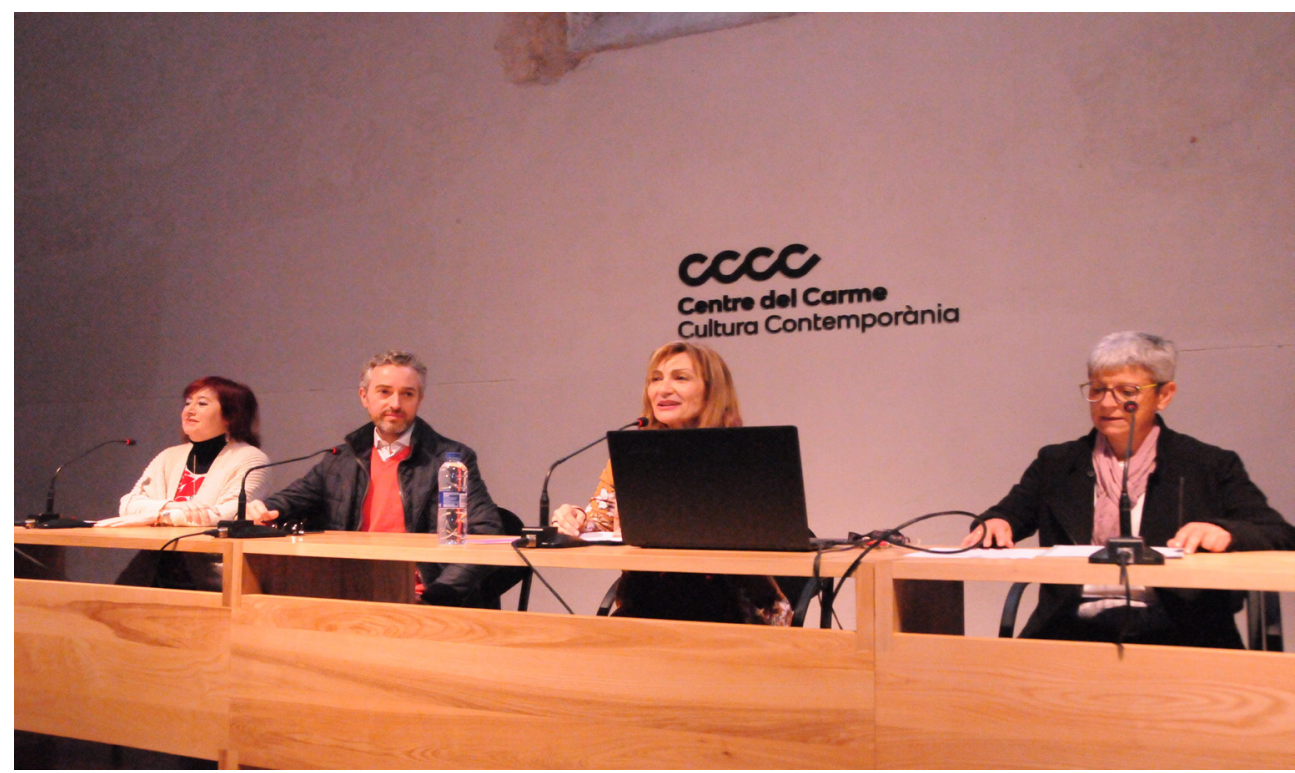

El 14 de abril de 2018 se celebró la V Jornada de Arteterapia y Educación: Identidad e identidades en el Espacio Educativo, en el bello marco del Centro de Cultura Contemporánea del Carme (CCCC) en la ciudad de Valencia.

El arteterapia se presenta y renueva en cada Jornada, tanto como un recurso educativo, en el reto de la educación por acoger la diversidad, como un espacio de confluencia a través del arte y la creación. Un lugar donde sorprender y dejarnos sorprender por quien es el otro, a través de sus obras y producciones. Un lugar donde fortalecer las inquietudes y las ilusiones que acompañan el proceso educativo, así como poner de manifiesto las dificultades que forman parte del día a día de la escuela y el instituto.

Esta nueva edición se orientó a reflexionar sobre el concepto de identidad e identidades en una escuela que pretende trascender la exclusión para ir hacia la integración de las diferencias. En las conferencias contamos con ponentes de larga trayectoria profesional como Fina Sanz y R. Lucas Platero, que disertaron sobre la actualidad de los conceptos de identidad y géneros.

En los talleres, que cumplen una función didáctica relevante en cada Jornada, porque es haciendo y viviendo como mejor se aprende, se abordaron temas tan inte- 
resantes como la creación de historias y narrativas a cargo de María Montero-Ríos y Ana Hernández, donde el lenguaje plástico, la ilustración y la fotografía se muestran como puertas a la observación y al descubrimiento. Con la Intervención de Anna Estellés en un taller donde el cuerpo y movimiento salen en busca de lo genuino, lo oscuro y lo luminoso de cada uno. Helena Sáez en su "Espacio de búsqueda y encuentro con uno mismo" abordó la búsqueda de identidades a través de la imagen, la fotografía y el cuerpo. Ángeles Herrero, planteó un taller de arteterapia a través de los dispositivos móviles. "Imágenes encontradas y materiales plásticos". Y finalmente Rubén E. Bild e Iván Gómez plantearon un taller de acompañamiento creativo. Todo ellos enfocados a la reflexión sobre como acoger y situar desde las artes y el arteterapia, en el marco educativo la diversidad de las identidades.

Por la tarde, en la mesa de debate, moderada Isabel Núñez, participaron las arteterapeutas en la puesta en común sus experiencias en educación, María Llanos Alonso, Ángeles Herrero, Patricia Marco y Mireia Martínez. Destacamos un dato relevante de los representantes de centros educativos, el IESS Comarcal, con Concepción Marí y Begoña Miranda, así como David Pérez de Cam niño Jesús. Y es el hecho de la disminución del absentismo escolar, el aumento del sentimiento de pertenencia al grupo y de integración en el centro, así como la bajada del nivel de agresividad y la mejora en la expresión emocional, el que los alumnos del master de arteterapia hacen prácticas

El encuentro fue un éxito de participación y aportaciones a la disciplina del Arteterapia en el ámbito educativo por la calidad de los talleres, mesa redonda y las conferencias que compartieron puntos de vista desde distintas perspectivas profesionales. Queda mucho por hacer para que la disciplina del arteterapia sea reconocida dentro del ámbito educativo, los profesionales ya lo hacen y demandan que los arteterapeutas colaboren en los programas de integración, pero falta una mayor sensibilidad de las instituciones y políticas educativas para dar el paso de la integración del arteterapia en las aulas, como ocurre en muchos países europeos.

El Equipo del Máster agradece enormemente los resultados, a todos los profesionales que participaron y aportaron lo mejor de ellos en la Jornada. También a las instituciones implicadas. Desde la organización, el Máster en Arteterapia de la UPV y el IDECART, representada por Susana García Rams, y Amparo Berenguer, con la colaboración del Consorci de Museus de la Generalitat Valenciana y su director José Luis Pérez Pont, desde el Vicerrectorado de Responsabilidad Social, Cooperación y Deporte, a cargo de Rosa Puchades. La Facultad de BBAA con el decano Pepe Galindo desde los Departamentos de Dibujo y Escultura de la Universitat Politècnica de València, dirigido por Antonio Alcaraz. Todos ellos han contribuido desde las distintas instituciones para promover un espacio de reflexión y coincidencia, abierto a las demandas de la profesión del arteterapia en un marco plural e interdisciplinar de temas y experiencias. 